\title{
Pembinaan Karakter Anak Usia Sekolah di Taman Pendidikan AlQur'an (TPA) Koto Kandis Kabupaten Pesisir Selatan
}

\author{
Vingki Elpani Putri, Azwar Ananda \\ Program Studi Pendidikan Pancasila dan Kewarganegaraan \\ Universitas Negeri Padang \\ Email : Vingkielpaniputri30@gmail.com
}

\begin{abstract}
ABSTRAK
Penelitian ini dilatar belakangi oleh adanya sikap dan perilaku anak usia sekolah yang tidak mencerminkan patuh terhadap ajaran agama dan dilihat dari aspek kedisiplinan banyak anak usia sekolah yang tidak menaati aturan dan tata tertib yang berlaku di Taman Pendidikan Al-Qur'an (TPA) Koto Kandis Kabupaten Pesisir Selatan. Tujuan penelitian ini adalah untuk mengetahui bentuk pembinaan karakter religius dan kedisiplinan anak usia sekolah di Taman Pendidikan Al-Qur'an (TPA) Koto Kandis Kabupaten Pesisir Selatan. Jenis Penelitian ini adalah kualitatif dengan menggunakan metode deskriptif karena penelitian ini berusaha menggambarkan dan melukiskan fakta-fakta secara akurat tentang suatu keadaan atau peristiwa yang tampak pada anak usia sekolah yang ada di Taman Pendidikan AlQur'an (TPA). Pemilihan informan dilakukan dengan teknik purposive sampling dengan informan sebanyak 16 orang informan.Hasil penelitian menunjukkan bahwa bentuk pembinaan karakter religius dan kedisiplinan yang dilaksanakan di Taman Pendidikan AlQur'an (TPA) Koto Kandis Kenagarian Kambang Kecamatan Lengayang Kabupaten Pesisir Selatan terdiri dari pembiasaan, keteladanan dan memberikan motivasi atau dorongan.Pembiasaan ini dilakukan dengan membiasakan murid untuk melaksanakan kegiatan yang berhubungan dengan agama dan kepercayaan.Pembinaan melalui keteladanan dilakukan oleh guru secara langsung melalui sikap dan perbuatannya.Sedangkan memberikan motivasi atau dorongan dilakukan oleh guru dengan memberikan penghargaan dan hukuman. Adapun kendala-kendala dalam pelaksanaan pembinaan karakter religius dan kedisiplinan di Taman Pendidikan Al-Qur'an (TPA) Koto Kandis Kabupaten Pesisir Selatan seperti waktu pelaksanaan yang kurang optimal, sarana dan prasarana yang tidak lengkap serta pemberian sanksi yang kurang tegas.
\end{abstract}

Kata Kunci: karakter, Taman Pendidikan Al-Qur'an

\section{ABSTRACT}

This research is motivated by the attitudes and behavior of school-age children who do not reflect compliance with religious teachings and viewed from the disciplinary aspects of many school-age children who do not obey the rules and regulations that apply in the Koto Kandis Al-Qur'an Education Park Regency of South Coast.The purpose of this study was to determine the form of religious character development and school-age child discipline in the 
Al-Qur'an Education Park (TPA) Koto Kandis, South Coastal District.This type of research is qualitative using descriptive methods because this research seeks to describe and describe facts accurately about a situation or event that appears in school-age children in the AlQur'an Education Park (TPA).The selection of informants was done by using purposive sampling technique with 16 informants.The results showed that the form of religious character development and discipline carried out in the Al-Qur'an Education Park (TPA) Koto Kandis Kenagarian Kambang Lengayang Subdistrict, Pesisir Selatan District consisted of habituation, example and provided motivation or encouragement. This habit is carried out by accustoming students to carry out activities related to religion and belief.Coaching through role models is done directly by the teacher through his attitude and actions. While providing motivation or encouragement is done by the teacher by giving awards and punishment. The obstacles in the implementation of religious character development and discipline in the AlQur'an Education Park (TPA) Koto Kandis, South Pesisir Regency such as less optimal implementation time, incomplete facilities and infrastructure as well as giving less strict sanctions.

Keywords : Character, Al-Qur'an Education Park

\section{PENDAHULUAN}

Pembinaan adalah suatu
bimbingan atau arahan yang
dilakukan secara sadar dari orang
dewasa kepada anak yang perlu dewasa agar menjadi dewasa, mandiri dan memiliki kepribadian yang utuh dan matang dalam mencapai aspek cipta, rasa dan karsa. Dalam buku Thoha (1997:16-17) dinyatakan bahwa pembinaan adalah suatu bentuk tindakan, proses, atau pernyataan agar menjadi lebih baik. Pembinaan diibaratkan sebagai suatu strategi yang unik dari suatu sistem berupa pembaharuan dan perubahan (change).

Menurut Sudewo (dalam Ananda: 2012) karakter adalah kumpulan sifat baik yang menjadi perilaku sehari-hari manusia yang diwujudkan melalui kesadaran dalam menjalankan peran, fungsi, dan tugasnya dalam menjalankan amanah dan tanggung jawab. Sedangkan menurut Scerenko (dalam Samani, Muchlas dan Hariyanto2011: 45), pendidikan karakter dapat dimaknai sebagai upaya bersungguh- sungguh dengan cara apa saja kepribadian positif dapat dikembangkan, didorong, serta diberdayakan melalui keteladanan, kajian, serta praktek dan usaha yang dilakukan secara maksimal. Berdasarkan pendapat tersebut dapat diketahui bahwa pendidikan karakter merupakan suatu usaha sungguh-sungguh supaya dapat mengembangkan sikap dan kepribadian yang baik dan sesuai dengan nilai-nilai dan norrma.

Penelitian yang dilakukan oleh Hakim (2014) menyebutkan bahwa Pendidikan Al-Qur'an berfungsi sebagai upaya pengenalan, pembiasaan, dan penanaman nilainilai pendidikan karakter mulia kepada peserta didik dalam rangka 
membangun manusia beriman dan bertaqwa kepada Allah SWT. Sedangkan menurut hasil penelitian Rozi (2017) menyatakan pembentukan karakter santri tidak terlepas dari peran penting para pendidik yang membimbing, melatih dan menasehati dalam membentuk karakter religius, mandiri, serta komunikatif terhadap santri di Taman Pendidikan Al-Qur'an AL-UBBAD Pondokrejo Kecamatan Tempurejo Kabupaten Jember. Berdasarkan penelitian di atas dapat diketahui bahwa peran pendidik sangat penting dalam membina pendidikan karakter terhadap santri seperti pengenalan, pembiasaan dan penanaman nilai-nilai karakter terhadap santri.

Penelitian yang dilakukan oleh peneliti sebelumnya berbeda dengan penelitian yang saya lakukan. Penelitian sebelumnya membahas tentang fungsi pendidikan Al-Qur'an dan peran pendidik dalam membentuk karakter religius, mandiri serta komunikatif santri di Taman Pendidikan Al-Qur'an. Penelitian yang akan peneliti lakukan lebih fokus pada bentuk pembinaan karakter religius dan kedisiplinan serta kendalakendala yang dihadapi dalam membina karakter tersebut.

Peneliti menemukan masalah dalam upaya membina karakter religius dan kedisiplinan di Taman Pendidikan Al-Qur'an (TPA) Koto Kandis Kabupaten Pesisir Selatan seperti masih banyak anak usia sekolah yang belum memiliki sikap dan perilaku yang mencerminkan patuh terhadap ajaran agama. Hal ini terbukti dengan banyaknya anak usia sekolah yang suka melalaikan shalat, bermain game saat belajar, berkata
Volume 1 No. 32018

tidak sopan dan minimnya pengetahuan keagamaan. Selain itu, permasalahan lainnya seperti masih banyaknya anak usia sekolah yang tidak memiliki sikap dan perilaku yang tidak menaati aturan yang berlaku di TPA. Hal ini dapat dibuktikan dengan banyaknya murid TPA yang datang terlambat ke TPA dan tidak berpakaian di TPA.

Oleh karena itu perlu adanya upaya pembinaan karakter religius anak usia sekolah di Taman Pendidikan Al-Qur'an (TPA) Koto Kandis Kabupaten Pesisir Selatan. Pembinaan karakter anak usia sekolah yang ada di TPA ini sudah dilaksanakan sejak beberapa tahun yang lalu dan berlangsung terusmenerus dalam membina karakter muridnya. Di daerah Koto Kandis Pesisir Selatan ini terdapat 6 Taman Pendidikan Al-Qur'an (TPA) yaitu TPA Surau Gadang Syekh H.Yahya, Baiturrahim, Nurul Ikhlas, Darul Ulum, Baiturrahman Kabun Randah dan Hidayatul Ikhlas, sehingga banyak anak usia sekolah yang belajar di TPA ini. Inilah sebabnya di daerah Koto Kandis Kabupaten Pesisir Selatan terdapat lembaga pendidikan non formal (TPA) sebagai penunjang pendidikan formal bagi anak usia sekolah.

Adapun tujuan pembinaan karakter anak usia sekolah di Taman Pendidikan Al-Qur'an (TPA) Koto Kandis Kabupaten Pesisir Selatan yaitu untuk menjadikan anak usia sekolah menjadi generasi yang patuh terhadap ajaran agama, berakhlak mulia dan disiplin dalam belajar. Penelitian ini bermanfaat bagi guru yang mengajar di TPA Koto Kandis dalam melaksanakan pembinaan 
karakter religius dan kedisiplinan anak usia sekolah untuk kedepannya supaya lebih dan optimal di Taman Pendidikan Al-Qur'an (TPA) Koto Kandis Kabupaten Pesisir Selatan.

\section{METODE PENELITIAN}

Jenis penelitian yang digunakan dalam penelitian ini adalah kualitatif dengan menggunakan metode deskriptif karena peneliti berusaha membuat deskripsi atau gambaran dan lukisan tentang suatu keadaan atau peristiwa sebagaimana adanya. Penentuan lokasi penelitian yaitu di Koto Kandis Pesisir Selatan berdasarkan pertimbangan dilatar belakang, waktu, biaya dan tempat. Dalam menetukan informan penelitian, peneliti menggunakan teknik Purposive Sampling karena informan dianggap sebagai orang yang benar-benar tau dan dapat memberikan informasi terkait penelitian. Informan dalam penelitian ini sebanyak 16 orang yang terdiri dari 1 Wali Nagari, 1 Kepala Kampung, 2 ketua pengelola, 2 tokoh masyarakat, 7 guru yang mengajar, dan 3 murid TPA.

Jenis data yang digunakan dalam penelitian ini menggunakan data primer dimana data diperoleh dari hasil observasi dan wawancara dilapangan sedangkan data skunder dalam penelitian ini diperoleh dari hasil studi dokumentasi di lokasi penelitian. Kemudian sumber data dalam penelitian ini didapatkan melalui informan penelitian.Teknik pengumpulan data dilakukan melalui observasi, wawancara dan studi dokumentasi. Untuk menguji keabsahan data dalam penelitian peneliti menggunakan teknik triangulasi. Teknik analisa data dilakukan melalui reduksi data, penyajian data dan penarikan kesimpulan.

\section{HASIL DAN PEMBAHASAN}

Bentuk-bentuk pembinaan karakter religius dan kedisiplinan anak usia sekolah di Taman Pendidikan AlQur'an (TPA) Koto Kandis Kabupaten Pesisir Selatan.

Karakter merupakan ciri khas yang dimiliki oleh seseorang yang berkaitan dengan sikap dan tingkah laku. Menurut Gunawan (2012:3-4), karakter merupakan perilaku manusia berkaitan dengan Tuhan Yang Maha Esa, diri individu, sesama manusia, lingkungan serta kebangsaan yang diwujudkan melalui pikiran, sikap, perasaan, perkataan, dan perbuatan berdasarkan norma yang berlaku. Pendidikan karakter adalah suatu gerakan nasional dalam suatu sekolah untuk mengembangkan peserta didik supaya memiliki etika, tanggung jawab, dan kepedulian dengan menerapkan dan mengajarkan nilainilai karakter melalui tekanan pada nilai-nilai yang berifat menyeluruh. Pendidikan karakter merupakan suatu usaha yang disengaja, proaktif yang dilakukan oleh sekolah dan pemerintah untuk menannamkan nilai-nilai inti seperti kepedulian, kejujuran, keadilan, tanggung jawab, dan penghargaan terhadap diri individu maupun orang lain (Yaumi, 2014:9-10).

Adapun bentuk-bentuk pembinaan karakter menurut Mulyasa (2012:165-181) antara lain pembiasaan dan keteladanan, pembinaan disiplin, hadiah dan hukuman, CTL (Contectual Teaching and Learning), bermain peran (role playing) dan pembelajaran parttisiptif (Partisipative instruction). Pembinaan karakter melalui pembiasaan dilakukan secara 
berulang-ulang agar sesuatu itu dapat menjadi kebiasaan. Pernyataan tersebut sesuai dengan hasil wawancara yang didapatkan di lapangan bahwa pembinaan karakter dilakukan oleh guru melalui pembiasaan. Pembiasaan yang dilakukan guru di Taman Pendidikan Al-Qur'an (TPA) Koto Kandis dalam membina karakter religius anak seperti membiasakan membaca do'a sebelum belajar, melaksanakan kegiatan 3S (Salam,Senyum,Sapa) dan giat belajar sedangkan dalam membina disiplin seperti membiasakan menaati aturan dan membiasakan menasehati murid.

Pembinaan karakter melalui keteladanan merupakan suatu hal berupa sikap dan perbuatan baik yang dapat ditiru atau dapat dijadikan contoh teladan.Keteladanan yang dimiliki guru sangat besar pengaruhnya terhadap pertumbuhan dan perkembangan peserta didik. Hal ini sesuai dengan hasil wawancara yang dilakukan dengan narasumber di lapangan bahwa pembinaan karakter dilakukan oleh guru melalui keteladanan. Bentuk-bentuk pembinaan melalui keteladanan karakter religius tersebut seperti mengumpulkan sumbangan, sabar menghadapi murid dan bersikap jujur sedangkan pembinaan keteladanan karakter disiplin seperti datang tepat waktu ke TPA dan disiplin dalam beribadah. Pembinaan keteladanan ini sudah dilakukan oleh guru di TPA Koto Kandis namun hasilnya belum optimal.

Pembinaan karakter melalui pemberian motivasi atau dorongan dengan memberikan penghargaan dan hukuman. Menurut teori S-R Bond menyatakan bahwa Reward and Punishment dapat digunakan untuk memperkuat respon positif atau respon negatif. Berdasarkan hasil temuan dilapangan dan wawancara yang dilakukan dengan narasumber di Taman Pendidikan Al-Qur'an (TPA) Koto Kandis penghargaan yang diberikan tidak hanya melalui materi namun juga melalui kata-kata pujian dan tepuk tangan. Memberikan penghargaan ini bertujuan supaya anak menjadi termotivasi dalam belajar dan semakin giat meraih prestasi.

Pemberian hukuman sebenarnya merupakan cara lain dalam mendidik anak, jika pendidik tidak bisa lagi memberikan nasehat, arahan, kelembutan, ataupun suri tauladan. Didalam metode Reward and Punishment pemberian hukuman bertujuan untuk mengubah dan memotivasi peserta didik sehingga peserta didik berlomba-lomba untuk menjauhi hukuman yang sudah ditentukan. Berdasarkan hasil temuan dan wawancara yang dilakukan dengan narasumber di lapangan guru selalu memberikan hukuman atau sanksi kepada murid yang melanggar atauran.Bentuk-bentuk pembinaan yang dilakukan dengan memberikan sanksi atau hukuman seperti membersihkan ruangan, menggulung tikar, menyetor hafalan dan membayar denda 2-3 buah buku tulis isi 40 .

Kendala-kendala dalam pembinaan karakter anak usia sekolah di Taman Pendidikan Al-Qur' an (TPA) Koto Kandis Kabupaten Pesisir Selatan.

Pembinaan karakter anak usia sekolah tidak terlepas dari kendalakendala yang dihadap oleh guru. Menurut Pitopang (Kompasiana, 2015) faktor-faktor yang mempengaruhi pelaksanaan pembelajaran di Taman 
Pendidikan Al-Qur'an (TPA) yaitu kurangnya SDM yang mengajar di TPA, tdak adaya kurikulum TPA, kurang solidnya hubungan masyarakat, kurangnya perhatian dari pengurus TPA dan kurangnya perhatian dari orang tua. Berdasarkan hasil temuan dan wawancara yang peneliti lakukan di lapangan kendalakendala dalam pembinaan karakter anak usia sekolah di Taman Pendidikan Al-Qur'an (TPA) Koto Kandis yaitu waktu pelaksanaan yang tidak optimal, minimnya sarana dan prasarana serta sanksi yang kurang tegas.

Waktu

pelaksanaan pembelajaran yang dilakukan di TPA Koto Kandis selama 60 menit yang dimulai pada pukul 19.00-20.00 WIB. Pembelajaran berlangsung setiap hari dengan materi pelajaran yang berbedabeda. Adapun pembelajaran yang diajarkan seperti baca tulis Al-Qur'an, praktek ibadah dan hafalan shalat, ilmu tajwid, pengetahuan keislaman, hafalan do'a dan surah pendek, irama, muhadarah, didikan subuh dan qasidah rabana.Pembelajaran tersebut tidak optimal karena hanya dilaksanakan selama 60 menit, apalagi sebelum pembelajaran dimulai anakanak dibimbing untuk membaca do'a terlebih dahulu sehingga terpakai waktu selama beberapa menit.

Sarana dan prasarana merupakan salah satu penunjang dalam pelaksanaan pembinaan karakter yang ada di Taman Pendidikan Al-Qur'an (TPA).berdasarkan hasil observasi dan wawancara dengan narasumber terkait sarana dan prasarana yang ada di TPA Koto Kandis masih terbilang minim. Beberapa sarana dan prasarana yang masih kurang di TPA Koto Kandis seperti meja, kursi, papan tulis, buku-buku dan ruangan belajar. Selain itu di TPA Koto Kandis ini tidak terdapat infokus sehingga guru mengajar hanya dengan metode ceramah saja yang membuat murid jenuh mendengarkan metode ceramah. Untuk membeli peralatan yang digunakan guru hanya menggunakan uang khas yang dibayar oleh murid sebesar RP.5.000 per orang, tentu saja uang tersebut tidak cukup untuk membeli peralatan yang dibutuhkan untuk belajar.

Kendala selanjutnya yaitu sanksi yang diberikan oleh guru kepada murid yang melanggar aturan kurang tegas. Berdasarkan hasil temuan di lapangan dan wawancara yang dilakukan dengan narasumber di Taman Pendidikan Al-Qur'an (TPA) Koto Kandis sanksi yang diberikan kepada murid kurang tegas sehingga beberapa orang murid sering menganggap remeh sanksi tersebut. Sebelum memberikan sanksi kepada murid biasanya guru menegur dan menasehati terlebuh dahulu, apabilah sudah ditegur dan dinasehati tetapi tetap tidak patuh maka guru memberikan sanksi atau hukuman. Beberapa bentuk hukuman yang dilakukan oleh guru di TPA Koto Kandis seperti membersihkan ruangan, menggulung tikar, menyetor hafalan dan membayar denda 2-3 buah buku tulis isi 40 .

\section{KESIMPULAN}

Berdasarkan uraian hasil penelitian tentang Pembinaan Karakter Anak Usia Sekolah di Taman Pendidikan Al-Qur'an (TPA) Koto Kandis Kabupaten Pesisir Selatan yang sudah peneliti jelaskan sebelumnya, dapat disimpulkan bahwa bentuk pembinaan karakter religius dan 
kedisiplinan yang dilakukan oleh guru yaitu melalui pembiasaan, keteladanan dan memberikan motivasi atau dorongan. Pembiasaan karakter religius yang dilakukan seperti membiasakan murid untuk membaca do'a sebelum belajar yang dibimbing oleh guru, membiasakan 3S (Salam, Senyum, Sapa) dan membiasakan giat belajar sedangkan pembiasaan karakter kedisiplinan seperti membiasakan menaati peraturan dan membiasakan menasehati murid. Bentuk keteladanan yang dilakukan oleh guru dalam membina karakter religius seperti mengumpulakn sumbangan, sabar menghadapi murid dan bersikap jujur sedangkan keteladanan karakter disiplin seperti datang tepat waktu ke TPA dan disiplin dalam beribadah. Memberikan motivasi atau dorongan dilakukan oleh guru dengan memberikan penghargaan seperti materi, pujian dan tepuk tangan sedangkan pemberian hukuman seperti membersihkan ruangan, menggulun tikar, menyetor hafalan dan membayar denda 2-3 buah buku tulis isi 40 .

Kendala-kendala yang dihadapi guru dalam pembinaan karakter religius dan kedisiplinan anak usia sekolah di Taman Pendidikan AlQur'an (TPA) Koto Kandis seperti waktu pembelajaran yang kurang optimal, sarana dan prasarana serta sanksi yang kurang tegas. Waktu pembelajaran berlangsung selama 60 menit sehingga tidak optimal untuk melaksanakan proses belajar mengajar. Sarana dan prasana yang ada di TPA Koto Kandis masih minim seperti meja yang tidak lengkap, kursi, papan tulis, buku-buku pelajaran yang tidak lengkap. Sanksi yang diberikan oleh guru tidak tegas sehingga murid sering menganggap remeh sanksi tersebut seperti membersihkan ruangan, menggulung tikar, menyetor hafalan dan membayar denda 2-3 buah buku tulis isi 40 .

\section{DAFTAR PUSTAKA}

Ananda, A. (2012). Pendidikan Kewarganegaraan dan Pendidikan Karakter Bangsa. Jurnal Demokrasi, 11(1).

Hakim, R. (2014). Pembentukan Karakter Peserta Didik Melalui Pendidikan Berbasis Al-Quran. Jurnal Pendidikan Karakter, (2). Kompasiana. 2015. Kendala-kendala dalam pembinaan karakter di TPA (diakses pada 19 juli 2019 jam 21.00 wib).

Mulyasa, E. (2011). Manajemen pendidikan karakter. Jakarta: Bumi Aksara, 165-189.

Rozi, M. F., Hendrawijaya, A. T., \& Imsiyah, N. (2017). PERAN PENDIDIK TERHADAP PEMBENTUKAN KARAKTER SANTRI DI TAMAN PENDIDIKAN AL-QUR'AN "AL-UBBAD" PONDOKREJO KECAMATAN TEMPUREJO KABUPATEN JEMBER. Learning Community: Jurnal Pendidikan Luar Sekolah, 1(1), 14-17.

Samani, M., \& Hariyanto, M. S. (2012). Konsep dan model pendidikan karakter. Bandung: Remaja Rosdakarya.

Thoha, Miftah. (1997). Pembinaan Organisasi. Jakarta: Rajawali Press.

Yaumi, M. (2014). Pendidikan karakter: Landasan, pilar dan implementasi. Jakarta: Prenada Media Group. 